\title{
NATURAL HISTORY AND BIOLOGY OF THE TIANNAN CROCODILE NEWT, TYLOTOTRITON YANGI (URODELA: SALAMANDRIDAE) AT GEJIU, YUNNAN PROVINCE, CHINA WITH ITS CONSERVATION IMPLICATIONS
}

\author{
Axel Hernandez ${ }^{1, *}$, Mian Hou ${ }^{2,3}$ \\ ${ }^{1}$ University Pasquale Paoli of Corsica, France \\ *e-mail: hernandez.axel.1989@gmail.com \\ ${ }^{2}$ Sichuan Normal University, China \\ ${ }^{3}$ Shenyang Normal University, China
}

Received: 05.03.2018

\begin{abstract}
The natural history of newly discovered species among the genus Tylototriton in South-Eastern Asia is poorly known to date, and most of the species are threatened by extinction. The description of their ecology is crucial to determine their survival status and successful reproduction for conservation purposes. In this study, we assessed the microhabitat preferences of Tylototriton yangi at the type locality, Gejiu, Yunnan province, China, with the Visual Encounter Survey method and by using new important materials. The main habitat is located within a humid subtropical climate and is composed of a large karstic mountain containing some patch of secondary mixed forests and plantations such as tomato fields, pepper and cabbage that are surrounded by scrubs, grasses and small ponds. We provided a complete diagnosis with new morphological data analysing ten adult individuals from the type series to establish a formal description which is absent from the first original description. We compared our results with other related taxa of the genus Tylototriton to updated key determinants between similar species. Thus, we analysed the population structure and the behaviour of $T$. yangi during a period of ten years, 2008-2017, to assess its survival status and to determine the main threat factors. A total of 186 specimens were found during the whole study predicting a small population inhabiting the type locality, Gejiu. Consequently, T. yangi is now regarded as a highly threatened species that need more attention of Chinese authorities and we suggest regarding it as Endangered due to its small distribution range, the low number of adult specimens observed and ongoing exploitation.
\end{abstract}

Key words: biology, China, conservation, ecology, Gejiu, microhabitat preferences, Tylototriton yangi, Yunnan province

\section{Introduction}

Newts and Salamanders belong to the Urodela group. This large group shows a high biodiversity on Earth (Dubois \& Raffaëlli, 2009, 2012; Raffaëlli, 2013; Frost, 2017; AmphibiaWeb, 2018). In the tropical-subtropical region, many new species were recently identified, and some families show an important endemism restricted to small habitats with specific ecological conditions (Hernandez, 2015, 2016b,e; Hernandez et al., 2017). In this case, one of the most interesting examples is the Salamandridae family that includes 119 species and occurs in the temperate regions of the northern hemisphere, but also in the tropical-subtropical region in southeast Asia (Duellman \& Trueb, 1986; AmphibiaWeb, 2018). This family appears broadly diversified in South-Eastern Asia, where five genera appear (Fei \& Ye, 2016; Hernandez et al., 2017). In the tropical region, cryptic popula- tions were found these last decades resulting in the description of several new species. It is observed especially within both the genera Echinotriton and Tylototriton, which form, together with the western Mediterranean Pleurodeles, the tribe Pleurodelini, a primitive lineage within the Salamandridae (Dubois \& Raffaëlli, 2009, 2012; Kurabayashi et al., 2012; Nishikawa et al., 2014, 2015; Marjanović \& Witzmann, 2015; Hernandez, 2016b,c,d,e). These urodeles are widely distributed from India to Indochina and South-Eastern China, with fossil specimens having been discovered here that are related to the first Urodela in the world (Wake \& Özeti, 1969). They are one of the few lineages of salamanders that appear in the tropical regions, with a poorly known ecology and natural history (Hernandez et al., 2017). Tylototriton and Echinotriton comprise more than 27 species with many undescribed taxa, and most of them are endangered pri- 
marily because of the habitat destruction in SouthEastern Asia (Seglie et al., 2003; Phimmachak et al., 2015; Hernandez, 2015, 2016b,c,d,e; Hernandez et al., 2017; Qian et al., 2017). During the last decade, new populations were identified and described in the Province of Yunnan, China, where an important evolutionary radiation occurred resulting from the Pleistocene glaciation among the «Tylototriton verrucosus» group, known as the subgenus Tylototriton (Hou et al., 2012; Yu et al., 2013). In 2009, the second author found at the pet market of Chengdu city many specimens sold as «Tylototriton verrucosus» for 6 to 10 euros that originated from southern Yunnan province without exact localities. In 2012, these specimens were localised around Gejiu city, Honghe Hani, and Yi Autonomous Prefecture, Yunnan province, China and then studied and described as a new valid species, Tylototriton yangi Hou, Zhang, Zhou, Li \& Lü, 2012 (Fei et al., 2006, 2012; Nishikawa et al., 2015; Fei \& Ye, 2016). In the past, this new species was reported and identified as «T. verrucosus» from eastern Yunnan province (Fei, 1996, 1999). The Tiannan Crocodile newt, Tylototriton yangi is a terrestrial salamander and endemic Chinese species. It inhabits the Karst Mountains including patch of secondary mixed forests with scattered water sources at relatively high elevations of 1600 to $1800 \mathrm{~m}$ a.s.1. (Hou et al., 2012; Fei et al., 2012; Fei \& Ye, 2016; Hernandez, 2016e). The species occurs at Gejiu in Honghe county, Honghe prefecture, Yunnan province, China, which is the type locality. Other localities known are distributed in Honghe and Wenshan Counties (Hou et al., 2012; Fei et al., 2012; Fei \& Ye, 2016). For this species, Fei et al. (2012), Raffaëlli (2013) and Sparreboom (2014) added an account in their books, and later we provided new data including a short diagnosis, some ecological and behavioural traits for a better understanding in a book on the genus Tylototriton (Hernandez, 2016e). Nishikawa et al. (2015) confirmed its taxonomic and phylogenetic position within Tylototriton and replaced the taxon $T$. daweishanensis Zhao, Rao, Liu, Li \& Yuan, 2012 as a junior synonym of $T$. yangi. Wang et al. (2017) studied the reproductive biology in captivity and explained the declining factors for this new species. New studies improved the short description for this species imported for the pet trade in mass. To date, limited information is known for T. yangi regarding its ecology and its microhabitat preferences since the original description (Hernandez, 2016e; Fei \& Ye, 2016; Wang et al., 2017). More- over, because the known distribution range of $T$. yangi overlaps greatly with the major tin-mining sites in southern China, the species is now threatened by extinction. Actually, its current status is not evaluated per IUCN criteria and the species is not protected in China (Hernandez, 2015; IUCN, 2017). In this alarming situation, we present here new major data regarding its ecology with a description of its biology to provide its requirements for conservation purposes.

Study site

The study area covered southern Yunnan province, China, including Honghe prefecture up to Xishuangbanna (Fig. 1). We recorded data for the microhabitat preferences of T. yangi in Gejiu, Honghe county, Honghe Hani, and Yi Autonomous Prefecture, Yunnan province, China, by field work during various months of the year (November and May to August) during a ten-year period (2008-2017) in Honghe Hani and Yi Autonomous Prefecture, Yunnan province, China $\left(22^{\circ} 50^{\prime} 07^{\prime \prime} \mathrm{N}, 102^{\circ} 17^{\prime} 06^{\prime \prime} \mathrm{E}\right)$, located at $1757 \mathrm{~m}$ a.s.l. A total of 186 specimens were found including adults, subadults and larvae during nighttime at 10:45 p.m. at the site. The climate of this region is humid subtropical ( $C f a$ and Cwa Köppen types; Peel et al., 2007; Baker et al., 2010) and humid tropical in the extreme southern part of the area, in Xishuangbanna autonomous prefecture ( $A w$ and $A m$ Köppen types; Peel et al., 2007).

\section{Climate}

The climate at Gejiu site is characterised by relatively high temperatures and evenly distributed precipitation throughout the year (Fig. 2). The Köppen Climate Classification subtype for this climate is «Cfa» Humid Subtropical Climate. According to WorldClim database (version 1.4), the average temperature for the whole year is $15.5^{\circ} \mathrm{C}$ for the last decade. On average, the warmest month is June with an average temperature of $19.9^{\circ} \mathrm{C}$. The coolest month on average is January, with an average temperature of $8.9^{\circ} \mathrm{C}$. The average amount of precipitation per year in Gejiu is $1308.1 \mathrm{~mm}$. The month with the most precipitation on average is July with $251.5 \mathrm{~mm}$ of precipitation. The month with the least precipitation on average is January with an average of $20.3 \mathrm{~mm}$. There is an average of 164.2 days of precipitation, with the most precipitation occurring in August with 23.9 days and the least precipitation occurring in February with 6.3 days (Fig. 3). In summer, these regions 
are largely under the influence of moist, maritime airflow from the western side of the subtropical anticyclonic cells over low-latitude ocean waters (Zhu, 1997; Zhu et al., 2005). Temperatures are high and can lead to warm, oppressive nights when the salamanders are active for reproduction. Summers are usually somewhat wetter than winters, with much of the rainfall coming from convectional thunderstorm activity; tropical cyclones also enhance warm-season rainfall in some regions. The coldest month is usually quite mild, although frosts are not uncommon, and winter precipitation is derived primarily from frontal cyclones along the polar front. Finally, our locality is characterised by a «humid subtropical climate» (Kottek et al., 2006, Baker et al., 2010). This climate is warm and temperate (Zhu et al., 2005). When compared with winter, the summers have much more rainfall. The average annual temperature is $17.2^{\circ} \mathrm{C}$ in Gejiu. About $1139 \mathrm{~mm}$ of precipitation falls annually. In summer, these regions are largely under the influence of moist, maritime airflow from the western side of the subtropical anticyclonic cells over low-latitude ocean waters. Temperatures are high and can lead to warm, oppressive nights. These parameters are important factors for the reproduction of the species as suggested for other salamandrid species (Hernandez, 2017).

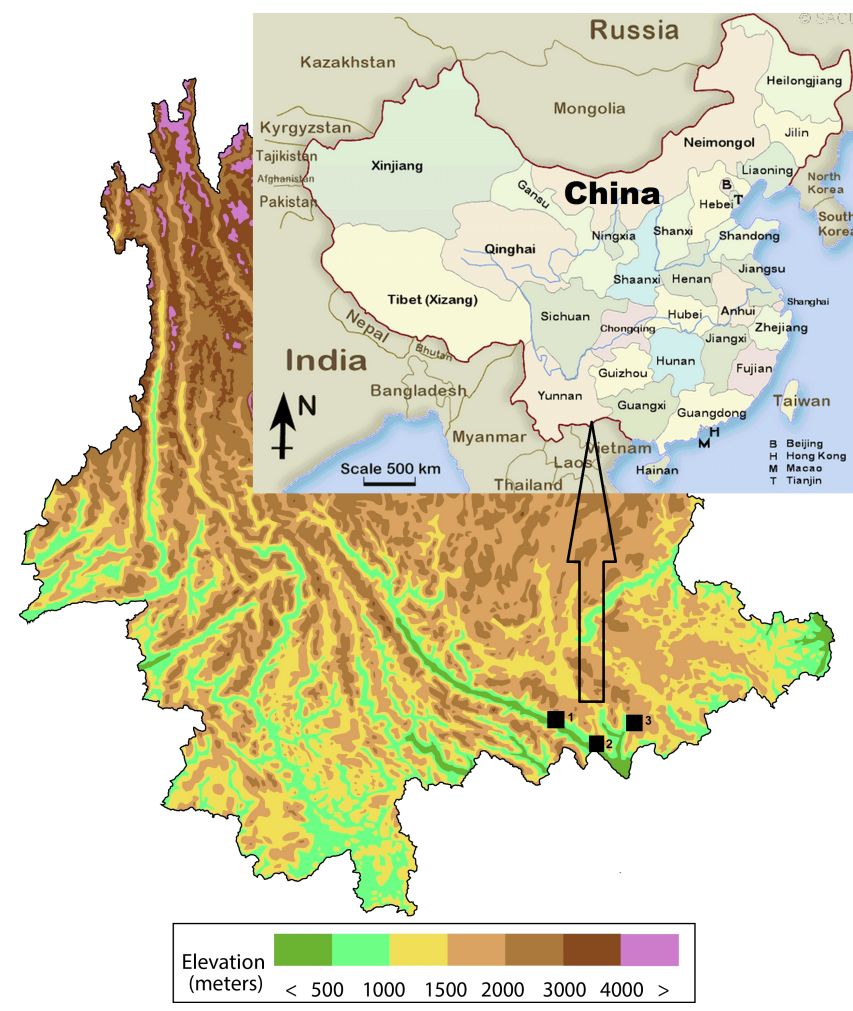

Fig. 1. Tylototriton yangi distribution including the three main populations found in Yunnan province, China. 1: Type locality at Gejiu (west); 2: Daweishan Nature Reserve (south); 3: Wenshan Nature Reserve (east).

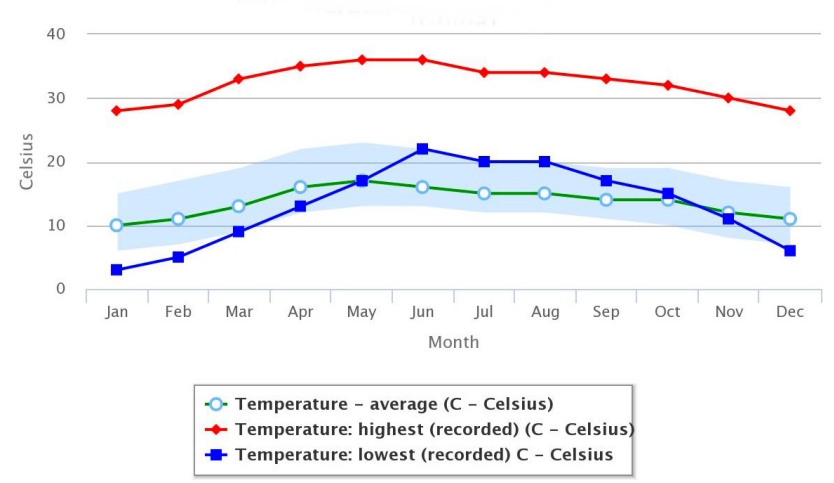

Fig. 2. Temperature $\left(\right.$ in $\left.{ }^{\circ} \mathrm{C}\right)$ recorded at Gejiu site, Yunnan province, China, in 2008-2017.

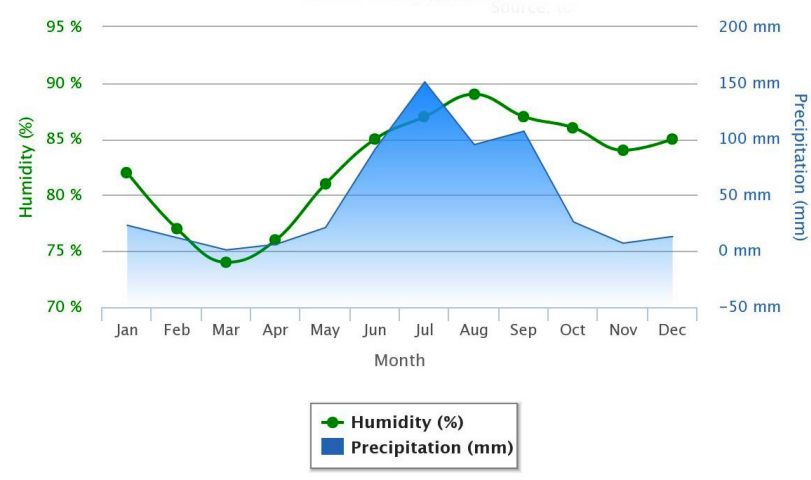

Fig. 3. Humidity and precipitation recorded at Gejiu site, Yunnan province, China, in 2008-2017.

\section{Field survey}

We prospected at the same site during various months of the year (November and May to August) during a ten-year period (2008-2017). The Visual Encounter Survey method (Hayer et al., 1994) was used for observing the crocodile newts. This method is cost effective and does not disturb the habitats of the target species (Ghimire \& Shah, 2014). Observations of the vegetation and habitat of the salamanders were carried out by conducting field trips both on sunny and on rainy days. Daily fieldwork was done approximately from 8:00 a.m. to 10:30 p.m., but sometimes later in the evening. For microhabitat study we surveyed almost all types of habitat found in the study area. These include permanent and temporary streams and ponds (including artificial reservoirs and irrigation canals) by means of dip-netting; and surrounding terrestrial habitats, removing stumps, stones and litter Microhabitat characteristics were recorded by collecting data regarding land type, water and soil temperature and type, weather condition, vegetation structure. Temperatures were recorded by using a mercury thermometer and photographs of the vegetation types using a digital camera (Sony Nex-5; Sony Ltd., Japan) throughout the 
whole period. Co-ordinates of each locality were collected in situ using a Global Positioning System (Garmin Montana 680; Garmin Ltd., Olahe, KS, USA) and located on maps. Chemical water parameters were measured in situ using a Expresstech @ LCD PH Medidor Digital (Expresstech; Kingpow Company Limited; Hong-Kong; China) for $\mathrm{pH}$. Climate and elevational data were obtained from the WorldClim database (version 1.4).

\section{Morphology}

Specimens studied for morphological description are derivated from Hou et al. (2012) and were collected by Hou Mian and Zhou Jia-Jun at Gejiu, Yunnan province, southern China $\left(23^{\circ} 21^{\prime} 35.8^{\prime \prime} \mathrm{N}\right.$, $103^{\circ} 09^{\prime} 59.0^{\prime \prime} \mathrm{E}$ ) at $2039 \mathrm{~m}$ a.s.l. in the summer periods of 2007-2008. They were fixed in 95\% alcohol after preserving muscle tissues in $95 \%$ alcohol. Adult specimens were later transferred to $75 \%$ alcohol. The ten specimens used for the original description are numbered from NO.SYNU-HM20070801-NT001 to NO.SYNU-HM20070801-NT010. They were deposited at Shenyang Normal University, Shenyang, China. A dial caliper was used (Louisware LSWCL1810, Louisware Ltd., USA) for measurements to the nearest $0.1 \mathrm{~mm}$. Examined specimens are listed in Table 1. Data for comparisons were obtained from description made by Fei et al. (2006, 2012).

\section{Results}

General characteristics. A total of 186 specimens were found during the ten-year period 2008-2017.

Morphometric characteristics. We analysed only ten specimens of the type series to study the morphology of the species and to establish a stable diagnosis. Data for T. shanjing Nussbaum, Brodie \& Yang, 1995, T. taliangensis Liu, 1950, T. kweichowensis Fang \& Chang, 1932 were obtained from Fei et al. $(2006,2012)$ and Fei \& Ye (2016) for comparison with our target species (Table 1).

Holotype. No. SYNU-HM20070801-NT001, is an adult male (Fig. 4A, 5A), collected at Gejiu, Yunnan province, China at $2205 \mathrm{~m}$ a.s.l. by Zhou Jia-jun in August 2007. It is the holotype used for the original description by Hou et al. (2012).

Allotypes. No. SYNU-HM20070801-NT002, adult female, other data are the same as those of the holotype (Fig. 4B, 5B).

Table 1. Measurements (mm) of Tylototriton yangi, T. shanjing, T. verrucosus, T. kweichowensis (subgenus Tylototriton) and T. taliangensis (subgenus Liangshantriton)

\begin{tabular}{|c|c|c|c|c|c|c|c|c|c|c|}
\hline \multirow[t]{2}{*}{ Measurements } & \multicolumn{2}{|c|}{$\begin{array}{c}\text { Tylototriton yangi Hou, } \\
\text { Zhang, Zhou, Li \& Lü, } 2012 \\
\text { (Gejiu, Yunnan, China) }\end{array}$} & \multicolumn{2}{|c|}{$\begin{array}{l}\text { Tylototriton shanjing Nuss- } \\
\text { baum, Brodie \& Yang, } 1995 \\
\text { (Jinggdong, Yunnan, China) }\end{array}$} & \multicolumn{2}{|c|}{$\begin{array}{c}\text { Tylototriton verrucosus } \\
\text { Anderson, } 1871 \text { (Kachin } \\
\text { state, Myanmar) }\end{array}$} & \multicolumn{2}{|c|}{$\begin{array}{l}\text { Tylototriton kweichowensis } \\
\text { Fang \& Chang, } 1932 \text { (Wein- } \\
\text { ing, Guizhou, China) }\end{array}$} & \multicolumn{2}{|c|}{$\begin{array}{l}\text { Tylototriton taliangensis } \\
\text { Liu, } 1950 \text { (Shimian, } \\
\text { Sichuan, China) }\end{array}$} \\
\hline & $\begin{array}{l}\text { Male } \\
\mathrm{n}=5\end{array}$ & $\begin{array}{c}\text { Female } \\
n=5\end{array}$ & $\begin{array}{c}\text { Male } \\
\mathrm{n}=10\end{array}$ & $\begin{array}{c}\text { Female } \\
n=10\end{array}$ & $\begin{array}{l}\text { Male } \\
\mathrm{n}=1\end{array}$ & $\begin{array}{c}\text { Female } \\
n=0\end{array}$ & $\begin{array}{c}\text { Male } \\
\mathrm{n}=13\end{array}$ & $\begin{array}{c}\text { Female } \\
n=6\end{array}$ & $\begin{array}{c}\text { Male } \\
\mathrm{n}=10\end{array}$ & $\begin{array}{c}\text { Female } \\
\mathrm{n}=10\end{array}$ \\
\hline SVLA & $\begin{array}{c}66.50 \sim \\
77.27\end{array}$ & $\begin{array}{c}74.87 \sim \\
91.82\end{array}$ & $\begin{array}{c}68.0 \sim \\
77.8\end{array}$ & $\begin{array}{c}80.2 \sim \\
86.3\end{array}$ & $\begin{array}{c}57.09 \sim \\
58.42\end{array}$ & $\begin{array}{c}59.52 \sim \\
60.96\end{array}$ & - & - & - & - \\
\hline SVLP & $\begin{array}{c}71.95 \sim \\
84.41\end{array}$ & $\begin{array}{c}81.39 \sim \\
98.62\end{array}$ & - & - & $\begin{array}{c}65.16 \sim \\
66.20\end{array}$ & $\begin{array}{c}65.48 \sim ~ \\
69.30\end{array}$ & $\begin{array}{c}81.0 \\
\sim 110.0\end{array}$ & $\begin{array}{c}101.0 \\
\sim 122.0\end{array}$ & $\begin{array}{c}87.0 \sim ~ \\
98.5\end{array}$ & $\begin{array}{l}93.0 \sim \\
111.0\end{array}$ \\
\hline AXGR & $\begin{array}{c}32.01 \sim \\
39.11\end{array}$ & $\begin{array}{c}37.09 \sim \\
47.41\end{array}$ & - & - & $\begin{array}{c}27.97 \sim \\
31.36\end{array}$ & $\begin{array}{c}29.04 \sim \\
32.30\end{array}$ & - & - & - & - \\
\hline TTL & $\begin{array}{c}126.55 \sim \\
157.95\end{array}$ & $\begin{array}{c}145.01 \sim \\
171.52\end{array}$ & $\begin{array}{c}136.0 \sim \\
150.0\end{array}$ & $\begin{array}{c}147.0 \sim \\
170.0\end{array}$ & $\begin{array}{l}122.05 \sim \\
124 . .47\end{array}$ & $\begin{array}{c}128.34 \sim ~ \\
135.52\end{array}$ & $\begin{array}{c}155.0 \sim \\
195.0\end{array}$ & $\begin{array}{c}177.0 \sim \\
210.0\end{array}$ & $\begin{array}{c}186.0 \sim \\
220.0\end{array}$ & $\begin{array}{c}194.0 \sim \\
230.0\end{array}$ \\
\hline TAL & $\begin{array}{c}44.24 \sim \\
75.17\end{array}$ & $\begin{array}{c}63.62 \sim \\
72.90\end{array}$ & $\begin{array}{c}60.0 \sim \\
75.5\end{array}$ & $\begin{array}{c}65.1 \sim \\
83.0\end{array}$ & $\begin{array}{c}55.85 \sim \\
59.31\end{array}$ & $\begin{array}{c}62.86 \sim \\
66.22\end{array}$ & $\begin{array}{c}59.0 \sim \\
85.0\end{array}$ & $\begin{array}{c}74.0 \sim \\
90.0\end{array}$ & $\begin{array}{l}99.0 \sim \\
130.0\end{array}$ & $\begin{array}{l}88.0 \sim \\
132.0\end{array}$ \\
\hline TAD & $\begin{array}{c}6.03 \sim \\
9.39\end{array}$ & $\begin{array}{c}5.84 \sim \\
9.33\end{array}$ & $\begin{array}{c}7.4 \sim \\
9.6\end{array}$ & $\begin{array}{c}7.5 \sim \\
9.6\end{array}$ & $\begin{array}{c}8.48 \sim \\
9.08\end{array}$ & $\begin{array}{c}5.08 \sim \\
8.11\end{array}$ & $\begin{array}{c}12.0 \sim \\
16.0\end{array}$ & $\begin{array}{c}11.0 \sim \\
15.0\end{array}$ & $\begin{array}{c}11.0 \sim \\
13.4\end{array}$ & $\begin{array}{c}10.0 \sim \\
12.0\end{array}$ \\
\hline HL & $\begin{array}{c}16.04 \sim \\
19.52\end{array}$ & $\begin{array}{c}18.78 \sim \\
22.01\end{array}$ & $\begin{array}{c}17.0 \sim \\
20.2\end{array}$ & $\begin{array}{c}18.9 \sim \\
21.5\end{array}$ & $\begin{array}{c}14.46 \sim \\
15.57\end{array}$ & $\begin{array}{c}13.97 \sim \\
15.47\end{array}$ & $\begin{array}{c}15.0 \sim \\
21.0\end{array}$ & $\begin{array}{c}18.0 \sim \\
22.0\end{array}$ & $\begin{array}{c}18.5 \sim \\
21.0\end{array}$ & $\begin{array}{c}19.6 \sim \\
22.7\end{array}$ \\
\hline HW & $\begin{array}{c}15.58 \sim \\
18.48\end{array}$ & $\begin{array}{c}16.88 \sim \\
20.34\end{array}$ & $\begin{array}{c}14.6 \sim \\
16.5\end{array}$ & $\begin{array}{c}15.8 \sim \\
18.3\end{array}$ & $\begin{array}{c}13.81 \sim \\
15.68\end{array}$ & $\begin{array}{c}13.74 \sim \\
14.22\end{array}$ & $\begin{array}{c}18.0 \sim \\
22.0\end{array}$ & $\begin{array}{c}20.5 \sim \\
21.0\end{array}$ & $\begin{array}{c}18.0 \sim \\
19.4\end{array}$ & $\begin{array}{c}18.7 \sim \\
20.8\end{array}$ \\
\hline EN & $\begin{array}{c}3.66 \sim \\
4.42\end{array}$ & $\begin{array}{c}3.63 \sim \\
5.01\end{array}$ & - & - & $\begin{array}{c}3.06 \sim \\
3.36\end{array}$ & $\begin{array}{c}3.56 \sim \\
4.39\end{array}$ & - & - & - & - \\
\hline IN & $\begin{array}{c}3.41 \sim \\
5.39\end{array}$ & $\begin{array}{c}4.22 \sim \\
5.50\end{array}$ & - & - & $\begin{array}{c}3.92 \sim \\
4.28\end{array}$ & $\begin{array}{c}3.58 \sim \\
3.60\end{array}$ & $\begin{array}{c}5.0 \sim \\
6.0\end{array}$ & $\begin{array}{c}5.0 \sim \\
5.5\end{array}$ & $\begin{array}{c}5.6 \sim \\
6.6\end{array}$ & $\begin{array}{c}5.4 \sim \\
6.8\end{array}$ \\
\hline $\mathrm{AL}$ & $\begin{array}{c}23.78 \sim \\
27.16\end{array}$ & $\begin{array}{c}25.88 \sim ~ \\
27.92\end{array}$ & $\begin{array}{c}21.2 \sim \\
24.0\end{array}$ & $\begin{array}{c}22.2 \sim \\
25.3\end{array}$ & $\begin{array}{c}18.04 \sim \\
19.63\end{array}$ & $\begin{array}{c}20.09 \sim \\
20.38\end{array}$ & - & - & - & - \\
\hline PL & $\begin{array}{c}23.84 \sim \\
30.51\end{array}$ & $\begin{array}{c}26.70 \sim \\
29.58 \\
\end{array}$ & $\begin{array}{c}21.5 \sim \\
24.5\end{array}$ & $\begin{array}{c}24.5 \sim \\
27.0\end{array}$ & $\begin{array}{c}21.56 \sim \\
21.60\end{array}$ & $\begin{array}{c}20.32 \sim \\
21.92 \\
\end{array}$ & - & - & - & - \\
\hline
\end{tabular}

SVLA = snout -vent length from tip of snout to anterior edge of vent; SVLP = snout-vent length from tip of snout to posterior edge of vent; $\mathrm{AXGR}=$ axilla to groin; $\mathrm{TTL}=$ total length; $\mathrm{TAL}=$ tail length from posterior edge of vent to tail tip; $\mathrm{TAD}=$ maximum tail depth; $\mathrm{HL}=$ head length from posterior edge of parotoid to snout tip; $\mathrm{HW}=$ maximum head width; $\mathrm{EN}=$ eye-nostril from anterior corner of eye to nostril; $\mathrm{IN}=$ internostril distance; $\mathrm{AL}=$ anterior limb length from axilla to tip of longest finger; $\mathrm{PL}=$ posterior limb length from groin to tip of longest toe. 




Fig. 4. Dorsal view of adult specimens of Tylototriton yangi: Aholotype male; B - allotype female (Author: M. Hou).

Paratypes. No. SYNU-HM20070801NT003 to SYNU-HM20070801-NT010, four adult males and four adult females. Collection data are the same as those of the holotype.

Analysis. All adult individuals are morphologically similar to the original diagnosis by Hou et al. (2012) and the descriptions from Fei et al. (2006, 2012), Fei \& Ye (2016) and Hernandez (2016e). The females are larger and more massive than the males, growing to 172 $\mathrm{mm}$ max. in TL, whereas males will measure only up to $158 \mathrm{~mm}$ (Fig. 4B).

Diagnosis. The snout is rounded, with pronounced cephalic edges (similar to T. kweichowensis), the vertebral line is prominent, the 15-16 dorsolateral glandular warts are clearly distinct, and the skin is distinctly warty. Both the upper and lower parts are black, and orange pigment is found on the parotoids from where a wide dorsal stripe continues to the tail, on the glandular warts, tips of fingers and toes, the cloaca, and the lateral and ventral parts of the tail.

Comparisons. T. yangi differs from all other known species by having a dark to black colouration on head, dorsum and venter; and a bright orange colouration on corners of the mouth, on dorsolateral glandular warts, parotoids, tail, fingers, toes and the cloacal region. Tylototriton yangi differs from $T$. kweichowensis by having separate and pronounced dorsolateral glandular warts. Tylototriton yangi differs from $T$. shanjing by having a black head, a large cranial forma-

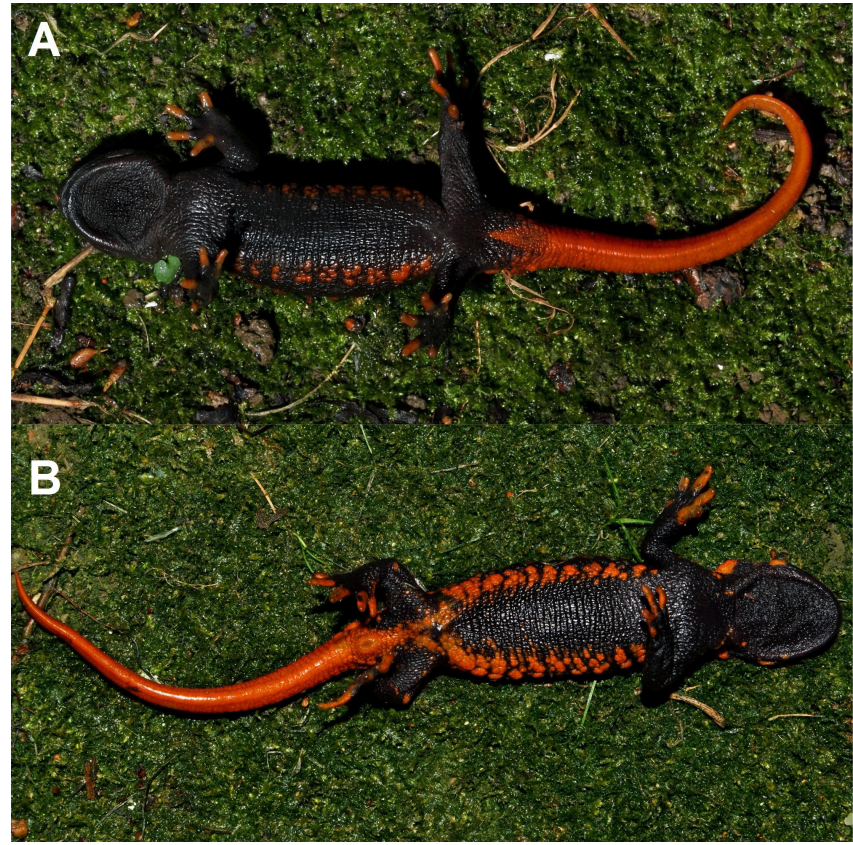

Fig. 5. Ventral view of T. yangi: A - holotype male; B - allotype female (Author: M. Hou).

tion (cephalic edges) and four black limbs. Tylototriton yangi differs from $T$. taliangensis and T. verrucosus Anderson, 1871 by having large cephalic edges, a bright red (orange) colouration on dorsolateral glands and tail. Tylototriton yangi differs from the subgenera Yaotriton and Liangshantriton by having a bright reddish to orange colouration on corners of the mouth, vertebral tubercular ridge, dorsolateral glandular warts well pronounced, large parotoids and tail.

Larvae. Larvae were collected at the same site in August 2008 by Hou Mian (Fig. 6). The larvae can be diagnosed as follow: Head flat, labial fold slender, costal groove next to invisibility. Dorsal fin beginning from posterior of the head, along with growth falls back on middle dorsal in gradual. The whole colouration is from light yellow change to tannish-gray or lilac in growth, have irregularly dark spot change to yellow or bluish-gray pattern on the whole length in growth. The colour changes deep. The gill disappears gradually during the growth. Some white spots present to hindbrain and lateral line will raise and the colour changes slowly, reaching to parotid and dorsolateral glandular warts. The spots on the tail will expand onto the whole tail by colouration change in reddish or orange.

Microhabitat composition and characteristics. The vegetation type is one of the key components of the Amphibians microhabitat because most of the species are dependent of 
the vegetation cover near water sources (Qian et al., 2007). Composition and characteristics of five different structural microhabitats of $T$. yan$g i$ are provided in Tables 2 and 3. Several plant species were identified within the 35 permanent quadrats: trees $(2.15 \%)$, shrubs $(44.08 \%)$, herbs $(31.19 \%)$, and grasses (22.58\%). Although specimens of $T$. yangi were found in the same habitat they have different microhabitat preferences and which varies during different parts of the day and the year, especially during the breeding period. In April up to the beginning of September, animals were found in ephemeral ponds and irrigated canals (Figs. 7 and 8). Ponds were semitransparent with a high concentration of phytoplankton and zooplankton. The soil was primarily silty clay and sandy loam. Thus, five microhabitats were analysed and classified corresponding to the species ecological preferences especially during the breeding period: 1) ephemeral ponds and water bodies with a total of 79 specimens found; 2) irrigation canals with 66 specimens; 3) soils and rich humus composed with fallen leaves with 21 specimens found mostly during the dry season; 4) amount of rocks with 15 specimens; 5) cultivated lands with only five specimens found including juveniles. These microhabitats were full of different species of trees, shrubs, herbs and grasses near to human habitation were identified as important to this salamander (Table 3 ).
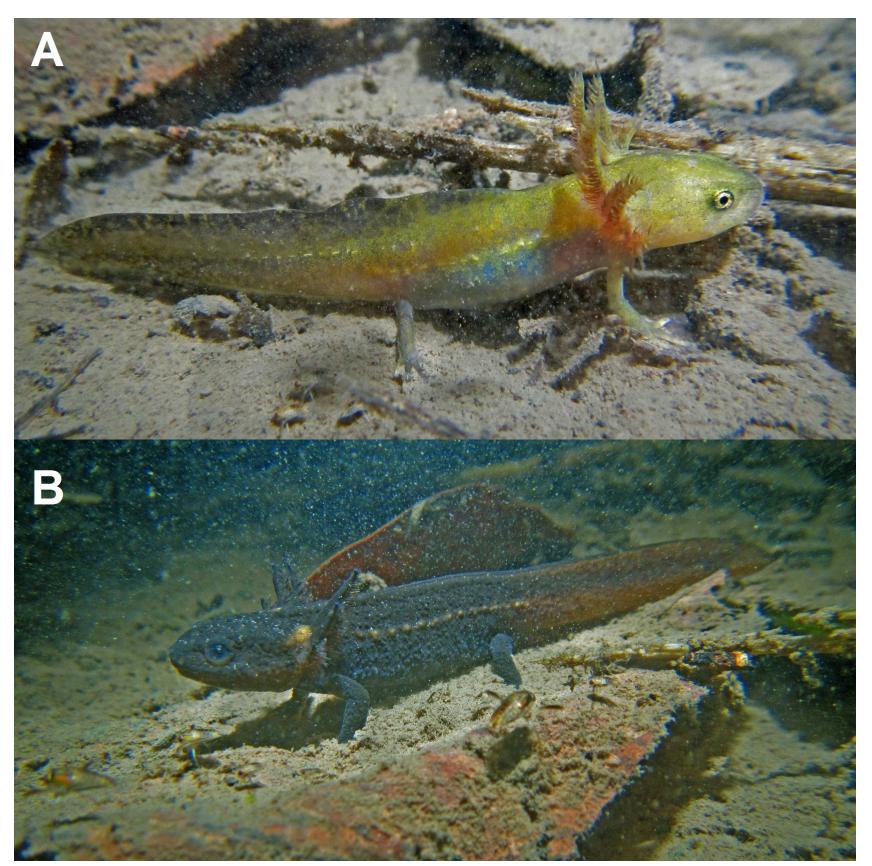

Fig. 6. Tylototriton yangi larvae. A - a larva of two months old, under water; B - a larva approaching metamorphosis (Authors: A. Hernandez and M. Hou).

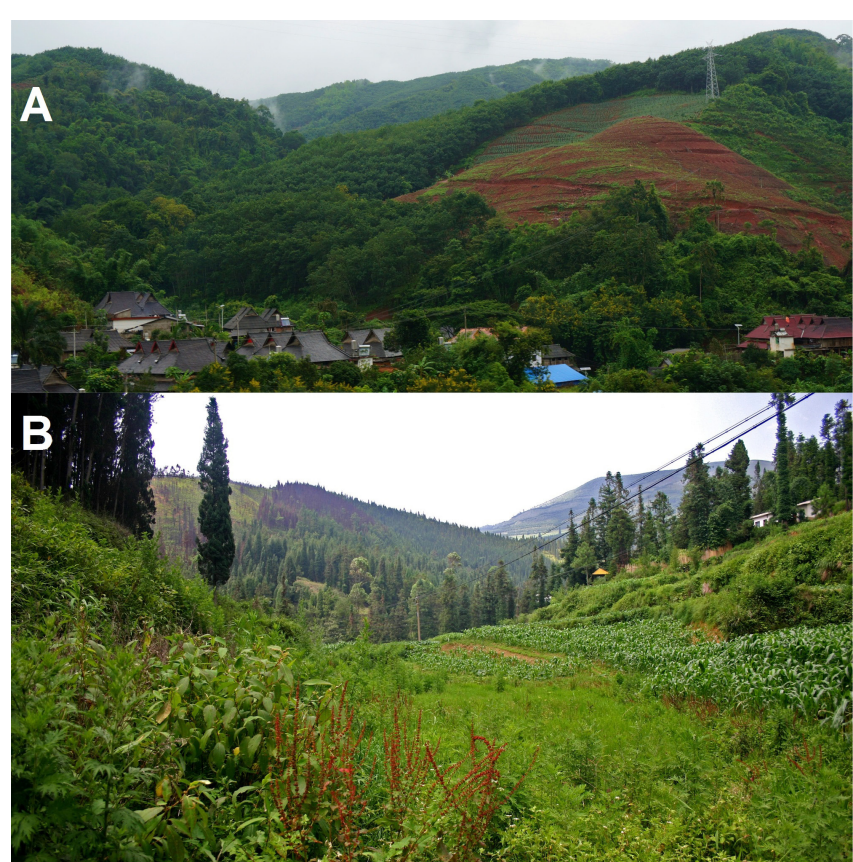

Fig. 7. General view of the main habitat of Tylototriton yangi at Gejiu, Yunnan province, China. A - destruction of the forests around Gejiu city on the mountain slopes; B - habitat of T. yangi surrounded by several crops (Author: A. Hernandez).

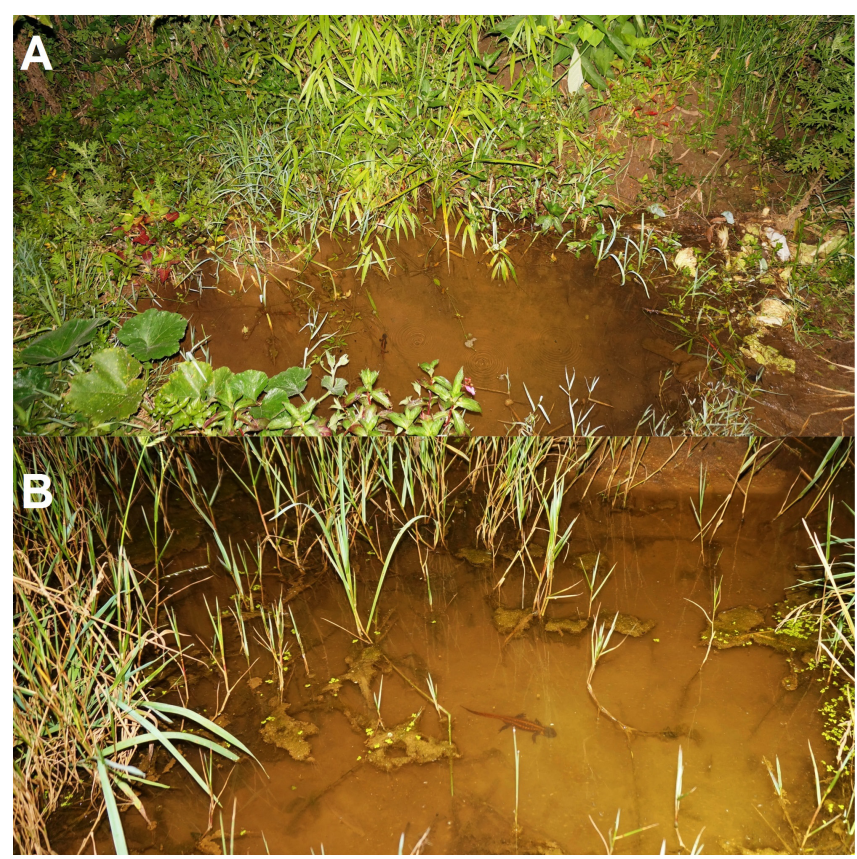

Fig. 8. Microhabitats of Tylototriton yangi at the type locality in 2015. A - a small breeding pond alimented by spring and summer rains; $\mathrm{B}$ - a large dam for irrigating plantations used as breeding site with a large adult female (Author: A. Hernandez).

Table 2. Vegetation type as a component of microhabitat of Tylototriton yangi at Gejiu, Yunnan province, China

\begin{tabular}{|c|c|c|c|}
\hline $\begin{array}{c}\text { Serial } \\
\text { number }\end{array}$ & $\begin{array}{c}\text { Vegetation } \\
\text { types }\end{array}$ & $\begin{array}{c}\text { Number } \\
\text { of specimens }\end{array}$ & Proportion (\%) \\
\hline 1 & Large trees & 4 & 2.15 \\
\hline 2 & Shrubs & 82 & 44.08 \\
\hline 3 & Herbs & 58 & 31.19 \\
\hline 4 & Grasses & 42 & 22.58 \\
\hline \multicolumn{2}{|c|}{ Total : } & 186 & 100 \\
\hline
\end{tabular}


Table 3. General description and composition of the microhabitats used by Tylototriton yangi at Gejiu, Yunnan province, China

\begin{tabular}{|c|c|c|c|c|c|c|c|c|}
\hline $\begin{array}{c}\text { Microhabitat } \\
\text { used }\end{array}$ & Composition & $\begin{array}{c}\text { Humidity } \\
(\%)\end{array}$ & $\mathrm{pH}$ & $\begin{array}{c}\text { Temperature } \\
\left({ }^{\circ} \mathrm{C}\right)\end{array}$ & $\begin{array}{c}\text { Number of } \\
\text { specimens } \\
\text { observed }\end{array}$ & Activity & Plant species & Presence of other taxa \\
\hline $\begin{array}{c}\text { Ephemeral } \\
\text { ponds and } \\
\text { water bodies }\end{array}$ & $\begin{array}{c}\text { Stagnant water bodies } \\
\text { are fed by slow- } \\
\text { flowing streams. They } \\
\text { are composed of clay } \\
\text { loam soils with dense } \\
\text { aquatic vegetation. } \\
\text { Water depth is about } \\
20 \text { to } 35 \mathrm{~cm}\end{array}$ & - & 7.7 & 19.9-21.9 & 79 & $\begin{array}{l}\text { Whole day with } \\
\text { a paroxysm of } \\
\text { activities during } \\
\text { April - May up } \\
\text { to June }\end{array}$ & $\begin{array}{l}\text { Rotala rotundifolia } \\
\text { (Buch.-Ham. ex } \\
\text { Roxb.) Koehne, } \\
\text { Hydrilla verticillata } \\
\text { (L.f.) Royle, Lemna } \\
\text { minor L., Azolla } \\
\text { imbricata (Roxb. } \\
\text { ex Griff.) Nakai, } \\
\text { Spirogyra } \text { sp., } \\
\text { Juncus effusus L. }\end{array}$ & \begin{tabular}{|l|} 
Babina pleuraden \\
(Boulenger, 1904), Kaloula \\
verrucosa Boulenger, 1904, \\
Microhyla sp., Lithobates \\
catesbeianus (Shaw, 1802), \\
Aquixalus sp., Nidi- \\
rana pleuraden (Boulenger, \\
1904), Duttaphrynus mela- \\
nostictus (Schneider, 1799), \\
Misgurnus anguillicaudatus \\
(Cantor, 1842), Pseudoras- \\
bora parva (Temminck \& \\
Schlegel, 1846), Rhodeus sp.
\end{tabular} \\
\hline $\begin{array}{l}\text { Irrigation } \\
\text { canals }\end{array}$ & $\begin{array}{l}\text { Highly vegetated with } \\
\text { aquatic plants. They } \\
\text { irrigate plantations } \\
\text { located } 2-5 \mathrm{~m} \text { away }\end{array}$ & - & 5.7 & $18.2-23.6$ & 66 & $\begin{array}{c}\text { Whole day with } \\
\text { a paroxysm of } \\
\text { activities during } \\
\text { April - May up } \\
\text { to June }\end{array}$ & \begin{tabular}{|l|} 
Rotala rotundifolia, \\
Hydrilla \\
verticillata, \\
Lemna minor, \\
Azolla imbricata, \\
Spirogyra sp., \\
Juncus effusus
\end{tabular} & $\begin{array}{l}\text { Babina pleuraden, Kaloula } \\
\text { verrucosa, Microhyla sp., } \\
\text { Lithobates catesbeianus, } \\
\text { Aquixalus } \text { sp., Nidirana } \\
\text { pleuraden, Duttaphrynus } \\
\text { melanostictus, Misgurnus } \\
\text { anguillicaudatus, Pseudoras- } \\
\text { bora parva, Rhodeus sp. }\end{array}$ \\
\hline $\begin{array}{c}\text { Soils and leaf } \\
\text { litters }\end{array}$ & $\begin{array}{c}\text { Fallen leaves are de- } \\
\text { posited on sandy loam } \\
\text { and silty clay soils }\end{array}$ & $\begin{array}{c}77.3-95.8 \\
\text { (high) }\end{array}$ & - & $16.1-17.6$ & 21 & $\begin{array}{l}\text { Specimens were } \\
\text { mainly found } \\
\text { during April to } \\
\text { September near } \\
\text { water bodies } \\
\text { under leaf litter }\end{array}$ & Bambusa spp. & \begin{tabular}{|l|} 
Lumbricina (earthworms), \\
Gastropoda (slugs and \\
snails), Hymenoptera (ants), \\
Dermaptera (earwigs), \\
Orthoptera (crickets and \\
grasshoppers), Coleoptera \\
(beetles)
\end{tabular} \\
\hline Rocks & $\begin{array}{c}\text { Large stones deposited } \\
\text { near water bodies }\end{array}$ & $76.8-97.6$ & - & $15.2-16.4$ & 15 & $\begin{array}{c}\text { Specimens were } \\
\text { found under rocks } \\
\text { at the end of } \\
\text { September }\end{array}$ & 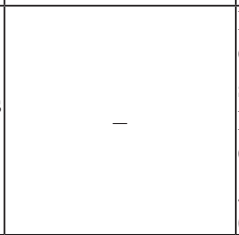 & $\begin{array}{l}\text { Lumbricina (earthworms), } \\
\text { Gastropoda (slugs and } \\
\text { snails), Hymenoptera (ants), } \\
\text { Dermaptera (earwigs), } \\
\text { Orthoptera (crickets and } \\
\text { grasshoppers), Coleoptera } \\
\text { (beetles) }\end{array}$ \\
\hline $\begin{array}{l}\text { Cultivated } \\
\text { lands }\end{array}$ & $\begin{array}{l}\text { Tomato plantations, } \\
\text { paddy fields. Presence } \\
\text { of fertilizers }\end{array}$ & $\begin{array}{c}64.1-74.3 \\
\text { (medium } \\
\text { to high) }\end{array}$ & - & $19.1-17.7$ & 5 & \begin{tabular}{|} 
Specimens were \\
found mostly \\
around water \\
bodies during the \\
nighttime in this \\
habitat
\end{tabular} & $\begin{array}{l}\text { Solanum lycoper- } \\
\text { sicum L., Brassica } \\
\text { rapa L., Lactuca } \\
\text { sativa L., Capsicum } \\
\text { spp. }\end{array}$ & $\begin{array}{l}\text { Gastropoda (slugs and } \\
\text { snails), Hymenoptera (ants), } \\
\text { Dermaptera (earwigs), } \\
\text { Orthoptera (crickets and } \\
\text { grasshoppers), Coleoptera } \\
\text { (beetles) }\end{array}$ \\
\hline
\end{tabular}

Habitat preferences. We found all of the specimens analysed in this study at Gejiu (Figs. 1 and 7). Xishuangbanna area seems to be a good place for T. yangi but no individuals were observed, only another sister species such as $T$. shanjing in new southern localities (Hernandez \& Hou, 2017). The habitat of Gejiu is located in a karstic mountain containing some patch of secondary mixed forests and plantations such as tomato fields, pepper and cabbage that are surrounded by scrubs, grasses and small ponds available for reproduction. Here, it shelters in leaf litter composed of large fallen leaves near the pools where humidity levels are very high (77.3-97.6\%). The studied site is located at high altitude with highly mineralised red and yellow soils including mainly sandy loam soils in large ponds and silty clay and several ephemeral water bodies. The air temperature was $20.9-22.4^{\circ} \mathrm{C}$ with a relative humidity of about $86 \%$ in July. The larvae were observed in six small ponds fed by slow-flowing streams and co-harbouring mol- lusks, fishes, tadpoles and crabs such as the following species: Babina pleuraden (Boulenger, 1904), Kaloula verrucosa Boulenger, 1904, Microhyla sp., Lithobates catesbeianus (Shaw, 1802), Aquixalus sp., Nidirana pleuraden (Boulenger, 1904), Duttaphrynus melanostictus (Schneider, 1799), Misgurnus anguillicaudatus (Cantor, 1842), Pseudorasbora parva (Temminck \& Schlegel, 1846), Rhodeus sp. (Table 3 ). The water is mainly acidic in all the water bodies analysed with an average of 6.7 .

Behaviour. The species is poorly active during the dry and winter period with only eight juveniles found during the whole study (October to March). It is a terrestrial species which is mainly adapted to the underground lifestyle. Adult specimens are fossorial such as T. kweichowensis and are living underground as previously reported during dry and cold periods (Hernandez, 2016e). The present study also shows that these Amphibians were more active in the early hours of the day (9.30-11.00 
a.m.) and during the beginning of the nighttime (6.30-11.30 p.m.). Most of the specimens found of T. yangi need a suitable microhabitat within their small terrestrial and aquatic ecosystems for survival purposes. Ephemeral water ponds and canals are crucial for its conservation. At Gejiu's site, the microenvironment which is important for the survival of this threatened species depends on many complex factors (Table 3):

i) The presence of water sources and large to small ephemeral ponds highly vegetated with aquatic plants;

ii) The nearest presence of shrubs, large rocks, pieces of mixed forests on clay loam soils.

iii) The presence of a various microfauna within the phyla Arthopoda and Mollusca.

Consequently, T. yangi remains almost inactive during the whole winter. Only some juveniles were active on the soil surface probably to find food resources. Its activity is highly associated with rhythm of precipitation and humidity especially between May up to September - October corresponding to its reproductive period (Fig. 3).

\section{Discussion}

The massive destruction of the natural habitat for the whole genus Tylototriton is a major threat in Asia which is explaining the important decrease of each species this last decade (Stuart et al., 2004, 2008; Phimmachak et al., 2015; Hernandez, 2015, 2016a,b,c,d,e; IUCN, 2017; AmphibiaWeb, 2018). Most of the species known and described recently are not distributed within protected areas and are not listed on the World or national IUCN Red Lists (Fei et al., 2006, 2012; Stuart et al., 2008; Raffaëlli, 2013; Hernandez, 2015; Khatiwada et al., 2015; Fei \& Ye, 2016). In this crisis and alarming context, $54.7 \%$ of threatened taxa of Newts and Salamanders are currently recognized (Hernandez, 2015). Therefore, new data are crucial for conservation purposes (Wake, 1991; Raffaëlli, 2013; Sparreboom, 2014). This cryptic genus contains up to date 24 species within the three subgenera Tylototriton, Liangshantriton and Yaotriton, while the sister genus Echinotriton contains only four species with one unnamed taxon from Amami island (Hernandez, 2016d,e). The subgenus Tylototriton comprises ten species: Tylototriton verrucosus Anderson, 1871; T. shanjing Nussbaum, Brodie \& Yang, 1995; T. pulcherrimus Hou, Zhang, Zhou, Li \& Lü, 2012; T. anguliceps Le, Nguyen, Nishikawa, Nguyen, Pham, Matsui, Bernardes \& Nguyen, 2015; T. podichthys Phimmachak, Aowphol \& Stuart, 2015; T. uyenoi
Nishikawa, Khonsue, Pomchote \& Matsui, 2013; T. yangi Hou, Zhang, Zhou, Li \& Lü, 2012; T. shanorum Nishikawa, Matsui \& Rao, 2014; T. himalayanus Khatiwada, Wang, Ghimire, Vasudevan, Paudel \& Jiang, 2016; T. kweichowensis Fang \& Chang, 1932. The subgenus Liangshantriton includes two endemic species from the Daliang Mts. adapted to high altitude in southern Sichuan province, China: T. taliangensis Liu, 1950 and T. pseudoverrucosus Hou, Gu, Zhang, Zeng \& Lü, 2012. The subgenus Yaotriton includes 12 species: Tylototriton asperrimus Unterstein, 1930; T. notialis Stuart, Phimmachak, Sivongxay \& Robichaud, 2010; T. hainanensis Fei, Ye \& Yang, 1984; T. vietnamensis Böhme, Schöttler, Nguyen \& Köhler, 2005; T. panhai Nishikawa, Khonsue, Pomchote \& Matsui, 2013; T. liuyangensis Yang, Jiang, Shen \& Fei, 2014; T. lizhenchangi Hou, Zhang, Jiang, Li \& Lü, 2012; T. broadoridgus Shen, Jiang \& Mo, 2012; T. wenxianensis Fei, Ye \& Yang, 1984; T. dabienicus Chen, Wang \& Tao, 2010; T. ziegleri Nishikawa, Matsui \& Nguyen, 2013; and T. anhuiensis Qian, Sun, Li, Guo, Pan, Kang, Wang, Jiang, Wu \& Zhang, 2017 (Hernandez, 2016d,e; Qian et al., 2017). Some species occur in disturbed areas with cultivated lands such as rice paddies and tea plantations, for instance $T$. verrucosus, $T$. shanjing, $T$. yangi, T. wenxianensis, and T. kweichowensis. But most of them are rather intolerant of habitat alterations (Hernandez et al., 2017). In this case, we studied Tylototriton yangi which is highly threatened by the loss of its habitat at Gejiu, Honghe prefecture, Yunnan province, China. To determine the survival future for this species we established its ecological characteristics requirements here. We recorded a total of 186 specimens. This low number shows there is a little population living at Gejiu. Tylototriton yangi inhabits the Karst Mountains between fields of mainly tomato, pepper and cabbage that are surrounded by tall grass and small ponds at relatively high elevations of 1600 to $2200 \mathrm{~m}$ a.s.l. The site is located under a humid subtropical climate with important precipitations that stimulate reproduction at the end of April up to September. The adults congregate in small and large ponds with dense aquatic vegetation where they mate in a kind of circular nuptial dance as observed in T. kweichowensis (Wang et al., 2017). However, some complete amplexus were also reported in captivity (Hernandez, 2017). At Gejiu site, it shelters in leaf litter near the pools where humidity levels are very high. Its natural diet consists of insects and mollusks. Adults and larvae were observed in six small ponds fed by slow-flowing streams and co- 
harbouring mollusks, tadpoles and crabs, with the latter of which being potential predators. During the winter (November to February), temperatures will not exceed $8.0^{\circ} \mathrm{C}$ at Gejiu and these salamanders are mostly inactive and live underground. Most of the specimens found of $T$. yangi need suitable microhabitats within their small terrestrial and aquatic complex ecosystems for survival purposes (Dasgupta, 1987, 1990; Seglie et al., 2003; Wang et al., 2017). Ephemeral water ponds and canals are crucial for its conservation. Concerning its morphology, this species exhibits morphological characters that are intermediate between $T$. shanjing and $T$. $k w e i c h o w e n s i s$ and shares with the latter species the black head (partially yellow in other species) (Hou et al., 2012; Fei et al., 2012). The females are larger and more massive than the males, growing to 17.2 $\mathrm{cm}$ max. TL, whereas males will measure only up to $15.8 \mathrm{~cm}$ (Hou et al., 2012; Fei et al., 2012; Fei \& Ye, 2016). The snout is rounded, with pronounced cephalic edges (similar to T. kweichowensis), the vertebral line is prominent, the 15-16 dorsolateral glandular warts are distinct, and the skin is distinctly warty. Both the upper and lower parts are black, and orange-yellow pigment is found on the parotoids from where a wide dorsal stripe continues to the tail, on the glandular warts, tips of fingers and toes, the cloaca, and the lateral and ventral parts of the tail. Regarding its range of distribution, only three localities are known to date. Next to the type locality which is Gejiu, Honghe County, Honghe Hani and Yi Autonomous Prefecture in southwestern Yunnan Province, China, other localities known are distributed in Honghe and Wenshan Counties, including Daweishan National Forest Park; Mengzi, Hekou and Wenshan National Nature Reserve, Laojunshan Mountains. This last locality is at the easternmost distribution limits of this species (Hernandez, 2016e). These localities are poorly surveyed and our study shows that the type locality is intensively cultivated for agriculture such as tomato plantations, pepper and cabbage that are surrounded by scrubs, grasses and small ponds available for reproduction. In this locality many factors could explain the presence of this species but our preliminary results need to be compared with the two other localities for a better understanding of their ecological requirements for their continued existence. Moreover, excessive collecting for the pet trade is another important threat for the species (Raffaëlli, 2013; Fei \& Ye, 2016; Wang et al., 2017). A year after its discovery in 2012, specimens were exported to Europe and the United States in numbers, decimating the wild pop- ulations to a major extent. The destruction through mining operations and pollution of their habitats with agrochemicals also pose substantial threats. A visit to these habitats in 2015 showed them to be highly degraded. Tylototriton yangi has furthermore been collected for traditional medicinal purposes for many years. Its current status is not evaluated per IUCN criteria and the species is not protected in China (Raffaëlli, 2013). In this alarming context, we should assess T. yangi as «Endangered» due to its small distribution, the three fragmented populations known with low number of adult individuals, and the different major threats described above (Hernandez, 2015, 2016b,e).

\section{Acknowledgements}

We want to express our particular thanks to Liang Fei, Changyuan Ye, Jean Raffaëlli, Guoha Yu, Jiang Jianping, Xie Feng, Geer Zhang, Daniel Escoriza, Emmanuel Jelsch, Jérôme Maran, Jia-jun Zhou and the Chengdu Institute of Biology. We also thank the following collaborators: Wu guanfu, Rao Ding-qi, Jiang Ke, Yunke Wu, Zhang Ming-wang, Zhao Hui, Yang Dian-cheng.

\section{References}

AmphibiaWeb. 2018. Amphibian Species of the World (ASW) version 5.6. Information on amphibian biology and conservation (web application). Berkeley. California. Available from: http:// amphibiaweb.org.

Baker B., Diaz H., Hargrove W., Hoffman F. 2010. Use of the Köppen-Trewartha climate classification to evaluate climatic refugia in statistically derived ecoregions for the People's Republic of China. Climatic Change 98(1): 113-131. DOI: 10.1007/s10584-009-9622-2

Dasgupta R. 1987. The construction of pools in parks and their relation to the conservation of small vertebrates. Journal of the Bengal Natural History Society. New Series 6(2): 110-112.

Dasgupta R. 1990. Distribution and conservation problems of the Himalayan newt (Tylototriton verrucosus) in the Darjeeling Himalayas. Hamadryad 15: 13-15.

Dubois A., Raffaëlli J. 2009. A new ergotaxonomy of the family Salamandridae Goldfuss, 1820 (Amphibia, Urodela). Alytes 26(1-4): 1-85.

Dubois A., Raffaëlli J. 2012. A new ergotaxonomy of the order Urodela Duméril, 1805 (Amphibia, Batrachia). Alytes 28(3-4): 77-161.

Duellman W.E., Trueb L. 1986. Biology of amphibians. New York: McGraw-Hill. 670 p.

Fei L. 1996. Atlas of amphibians of China. Chengdu: Cheng$\mathrm{du}$ Institute of Biology. $432 \mathrm{p}$.

Fei L. 1999. Atlas of amphibians of China. Zhengzhao, China: Hunan Science and Technology Publishing House. 432 p.

Fei L., Ye C. 2016. Amphibians of China. Vol. 1. Beijing: Science Press Beijing. 1040 p. [In Chinese] 
Fei L., Ye C.Y., Jiang J.P. 2012. Coloured Atlas of Chinese amphibians and Their Distributions. Chengdu: Sichuan Publishing House of Science and Technology. 620 p. [In Chinese]

Fei L., Ye C.Y., Huan Y.Z., Jiang J.P., Xie F. 2006. An illustrated key to Chinese amphibians. Chengdu: Sichuan Publishing House of Science and Technology. 340 p. [In Chinese]

Frost D. 2017. Amphibian Species of the World: an Online Reference. Version 6.0. New York, USA: American Museum of Natural History. Available from: http://research.amnh.org/herpetology/amphibia/index.html. Retrieved on 23 April 2017.

Ghimire H.R., Shah K.B. 2014. Status and habitat ecology of the yellow monitor, Varanus flavescens, in the southeastern part of Kanchanpur district, Nepal. Herpetological Conservation and Biology 9(2): 387-393.

Hayer W.K., Donnelly M.A., McDiamid R.W., Hayekand L.C., Foster M.S. (Eds.). 1994. Measuring and Monitoring Biodiversity, standard methods for amphibians. Washington: Smithsonian Institution Press. 364 p.

Hernandez A. 2015. Etude des Amphibiens Urodèles en voie d'extinction et mise en place de projets de conservation au Parc Zoologique de Thoiry. MSc. Thesis, Part 1. Corte: University of Corsica. 224 p.

Hernandez A. 2016a. Etude sur les Urodèles en voie de disparition. Paris: Éditions Édilivre. 120 p.

Hernandez A. 2016b. Tylototriton Anderson, 1871: Observation du genre en Thaïlande et éléments de réflexions sur la diversité des sous-genres Yaotriton et Tylototriton. AFT, Revue Francophone d'Herpétoculture, Situla 28: 12-25.

Hernandez A. 2016c. Le genre relicte Echinotriton Nussbaum \& Brodie, 1982 en Asie du sud-est, AFT, Revue Francophone d'Herpétoculture, Situla 29: 18-31.

Hernandez A. 2016d. Le genre Echinotriton en Asie du sudest: de véritables fossiles au bord de l'extinction. Paris: Éditions Édilivre. 70 p.

Hernandez A. 2016e. Crocodile newts: The primitive Salamandridae from Asia (the genera Echinotriton and $T y$ lototriton). Frankfurt: Edition Chimaira. 415 p.

Hernandez A. 2017. Les Urodèles du Maroc: Pleurodeles waltl, Salamandra algira tingitana, S. algira splendens et $S$. algira spelaea (Caudata : Salamandridae), Histoire naturelle, taxinomie, écologie et perspectives conservatoires. AFT, Revue Francophone d'Herpétoculture, Situla 30: 30-48.

Hernandez A., Escoriza D., Hou M. 2017. Habitat selection of the endangered crocodile newts Echinotriton (Amphibia: Salamandridae): a preliminary assessment. Bulletin de la Société Herpétologique de France 163: 21-34.

Hernandez A., Hou M. 2017. New localities of Tylototriton shanjing Nussbaum, Brodie \& Yang, 1995 at its southern limit of distribution in Yunnan province, China. Bulletin de la Société Herpétologique de France 163: 103-105.

Hou M., Li P.P., Lü S.Q. 2012. Morphological research development of genus Tylototriton and primary confirmation of the status of four cryptic populations. Journal of Huangshan University 14: 61-65.

IUCN. 2017. The IUCN Red List of Threatened Species. Ver- sion 2014.3. Available from: http://www.iucnredlist. org. Retrieved on 17 November 2017.

Khatiwada J.R., Wang B., Ghimire S., Vasudevan K., Paudel S., Jiang J. 2015. A new species of the genus Tylototriton (Amphibia: Urodela: Salamandriae) from Eastern Himalaya. Asian Herpetological Research 6(4): 245 256. DOI: 10.16373/j.cnki.ahr.170013

Kottek M., Grieser J., Beck C., Rudolf B., Rubel F. 2006. World map of the Köppen-Geiger climate classification updated. Meteorologische Zeitschrift 15(3): 259-263. DOI: 10.1127/0941-2948/2006/0130

Kurabayashi A., Nishitani T., Katsuren S., Oumi S., Sumida M. 2012. Mitochondrial genomes and divergence times of crocodile newts: Inter-islands distribution of Echinotriton andersoni and the origin of a unique repetitive sequence found in Tylototriton $\mathrm{mt}$ genomes. Genes \& Genetic Systems 87(1): 39-51. DOI: 10.1266/ggs.87.39

Marjanović D., Witzmann F. 2015. An extremely peramorphic newt (Urodela: Salamandridae: Pleurodelini) from the Latest Oligocene of Germany, and a new phylogenetic analysis of extant and extinct Salamandrids. PLOS ONE 10: e0137068. DOI: 10.1371/journal.pone.0137068

Nishikawa K., Matsui M., Rao D.Q. 2014. A new species of Tylototriton (Amphibia: Urodela: Salamandridae) from central Myanmar. Natural History Bulletin of the Siam Society 60(1): 9-22.

Nishikawa K., Rao D-q., Matsui M., Eto K. 2015. Taxonomic relationship between Tylototriton daweishanensis Zhao, Rao, Liu, Li and Yuan, 2012 and $T$. yangi Hou, Li and Liu, 2012 (Amphibia: Urodela: Salamandridae). Current Herpetology 34: 67-74. DOI: $10.5358 /$ hsj.34.67

Peel M.C., Finlayson B.L., McMahon T.A. 2007. Updated world map of the Köppen-Geiger climate classification. Hydrology and Earth System Sciences Discussions 4: 439-473. DOI: 10.5194/hess-11-1633-2007

Phimmachak S., Aowphol A., Stuart B. 2015. Morphological and molecular variation in Tylototriton (Caudata: Salamandridae) in Laos, with description of a new species. Zootaxa 4006(2): 285-310. DOI: 10.11646/zootaxa.4006.2.3

Qian H., Wang X., Wang S., Li Y. 2007. Environmental determinants of amphibian and reptile species richness in China. Ecography 30: 471-482. DOI: 10.1111/j.0906-7590.2007.05025.X

Qian L., Sun X., Li J., Guo W., Pan T., Kang X., Wang H., Jiang J., Wu J., Zhang B. 2017. A new species of the genus Tylototriton (Amphibia: Urodela: Salamandridae) from the southern Dabie Mountains in Anhui province. Asian Herpetological Research 8(3): 151-164. DOI: 10.16373/j.cnki.ahr.170013

Raffaëlli J. 2013. Les Urodèles du monde. Penclen: Deuxième Édition. 480 p.

Seglie D., Roy D., Giacoma C., Mushahidunnabi M. 2003. Distribution and conservation of the Himalayan Newt (Tylototriton verrucosus, Urodela, Salamandridae) in the Darjeeling District, west Bengal (India). Russian Journal of Herpetology 10(2): 159-164.

Sparreboom M. 2014. Salamanders of the old world. Zeist, Netherland: KNNV Publishing. 432 p. 
Stuart S.N., Chanson J.S., Cox N.A., Young B.E., Rodrigues A.SL., Fischman D.L., Waller R.W. 2004. Status and trends of Amphibian declines and extinctions worldwide. Science 306(5702): 1783-1786. DOI: 10.1126/science.1103538

Stuart S.N., Hoffmann M., Chanson J.S., Cox N.A., Berridge R.J., Ramani P., Young B.E. 2008. Threatened amphibians of the World. Barcelona, Spain: Lynx Edicions. 758 p.

Wake D.B. 1991. Declining amphibian populations. Science 253(5022): 860. DOI: 10.1126/science.253.5022.860

Wake D.B., Özeti N. 1969. Evolutionary relationships in the family Salamandridae. Copeia 1969: 124-137.

Wang K., Yuan Z., Zhong G., Li G., Verrell P.A. 2017. Reproductive biology of Tylototriton yangi (Urodela: Salamandridae), with suggestions on its conservation. Amphibian \& Reptile Conservation 11(2): 33-43.
Yu G., Zhang M., Rao D., Yang J. 2013. Effect of Pleistocene climatic oscillations on the phylogeography and demography of red knobby newt (Tylototriton shanjing) from Southwestern China. PloS ONE 8(2): e56066. DOI: 10.1371/journal.pone.0056066

Zhu H. 1997. Ecological and biogeographical studies on the tropical rain forest of south Yunnan, SW China with a special reference to its relation with rain forests of tropical Asia. Journal of Biogeography 24(5): 647662. DOI: 10.1111/j.1365-2699.1997.tb00075.x

Zhu H., Shi J.P., Zhao C.J. 2005. Species composition, physiognomy and plant diversity of the tropical montane evergreen broad-leaved forest in southern Yunnan. Biodiversity and Conservation 14(12): 2855-2870. DOI: 10.1007/s10531-004-8220-x

\title{
ЕСТЕСТВЕННАЯ ИСТОРИЯ И БИОЛОГИЯ ТИАННАНСКОГО КРОКОДИЛОВОГО ТРИТОНА, ТYLOTOTRITON YANGI (URODELA: SALAMANDRIDAE) В ГЭЦЗЮ (ПРОВИНЦИЯ ЮННАНЬ, КИТАЙ) С ПРЕДПОСЫЛКАМИ ДЛЯ ЕГО ОХРАНЫ
}

\author{
А. Эрнандес ${ }^{1, *}$, М. Хоу ${ }^{2,3}$ \\ ${ }^{1}$ Университет Корсики, Франция \\ *e-mail: hernandez.axel.1989@gmail.com \\ ${ }^{2}$ Университет в Сычуани, Китай \\ ${ }^{3}$ Университет в Шеньяне, Китай
}

Естественная история вида рода Tylototriton, недавно описанного из Юго-Восточной Азии, к настоящему времени мало известна. Большинство представителей этого рода находится под угрозой исчезновения. Описание их экологии важно для определения возможностей их выживания и успешного их воспроизведения, способствующих их сохранению. В настоящем исследовании мы оценили предпочтения Tylototriton yangi к условиям микросреды обитания в типовом локалитете, Гэцзю, провинция Юннань, Китай. Мы использовали метод визуального наблюдения в сочетании с новыми важными материалами. Основная среда обитания расположена в условиях влажного субтропического климата. Это большая карстовая гора, на которой расположен участок вторичных смешанных лесов и плантаций таких растений, как томаты, перец и капуста, окруженных кустарниками, травянистой растительностью и небольшими прудами. Мы представили полный диагноз вида с новыми морфологическими данными по результатам анализа десяти взрослых особей из типовой серии для установления формального описания, которое отсутствует в первом оригинальном описании таксона. Мы провели сравнение наших результатов с остальными близкими таксонами рода Tylototriton для установления ключевых отличительных черт между близкими видами. Таким образом, мы проанализировали структуру популяции и поведение T. yangi в течение десяти лет, 2008-2017 гг., для оценки его статуса выживания и определения основных угроз. За весь период исследований мы обнаружили в общей сложности 186 особей, что свидетельствует о небольшом размере популяции, населяющей типовой локалитет вида в Гэцзю. Следовательно, на данный момент очень высока угроза исчезновения T. yangi, которому необходимо уделять больше внимания со стороны властей Китая. Мы предлагаем рассматривать его статус как находящийся под угрозой исчезновения (Endangered) в связи с его небольшим ареалом распространения, малым количеством обнаруженных взрослых особей и продолжающейся эксплуатацией природных ресурсов.

Ключевые слова: Tylototriton yangi, биология, Гэцзю, Китай, предпочтения микросреды обитания, провинция Юннань, сохранение, экология 